\title{
ANALISIS PENGARUH SKILL VARIETY, TASK IDENTITY, TASK SIGNIFICANCE, AUTONOMY, FEEDBACK ABOUT RESULT DAN KEPUASAN KERJA TERHADAP KINERJA DOSEN UNIVERSITAS PAMULANG UNTUK PENGEMBANGAN KARIR DAN PENGEMBANGAN ORGANISASI
}

\author{
FIKA RAHMANITA ${ }^{1)}$, ERI WIRANDANA ${ }^{2)}$ \\ Dosen Program Studi Pendidikan Ekonomi Universitas Pamulang \\ dosen01930@unpam.ac.id ${ }^{1}$, eriwirandana7@gmail.com ${ }^{2}$
}

\begin{abstract}
ABSTRAK
Undang-undang Republik Indonesia Nomor 12 Tahun 2012 menyebutkan bahwa: "dosen adalah pendidik profesional dan ilmuwan dengan tugas utama mentransformasikan, mengembangkan, dan menyebarluaskan Ilmu Pengetahuan dan Teknologi melalui Pendidikan, Penelitian, dan Pengabdian kepada Masyarakat." Pengembangan organisasi merupakan strategi organisasi yang dilakukan untuk mencapai perubahan secara organisasional terutama meningkatkan kinerja dosen. Tahap pertama dalam kegiatan ini adalah dengan melakukan diagnosis pada level individu untuk mengetahui permasalahan yang ada sehingga kemudian bisa ditentukan solusi yang sesuai untuk menyelesaikan permasalahan. Diagnosis pada level individu dilakukan untuk mendiagnosa bagaimana pengaruhnya terhadap kinerja. Penelitian ini menggunakan metode survei dengan teknik pengambilan sampel purposive sampling. Metode kuantitiatif dalam penelitian ini dikembangkan dengan metode kausalitas dengan PLS sebagai teknik analisis data. Hasil penelitian menunjukkan terdapat variabel yang mempengaruhi kinerja yaitu task significance dan feedback about result.
\end{abstract}

Kata Kunci: skill variety, task significance, task identity, autonomy, feedback about result, kinerja, kepuasan kerja 


\section{PENDAHULUAN}

Dosen memiliki tanggung jawab untuk menjalankan kewajiban me-nyelenggarakan pendidikan, penelitian, dan pengabdian kepada masyarakat. Tridharma bertujuan untuk mensejahterakan masyarakat dan mencerdaskan kehidupan bangsa. Undang-undang Republik Indonesia Nomor 12 Tahun 2012 menyebutkan bahwa: "dosen adalah pendidik profesional dan ilmuwan dengan tugas utama mentransformasikan, mengembangkan, dan menyebarluaskan Ilmu Pengetahuan dan Teknologi melalui Pendidikan, Penelitian, dan Pengabdian kepada Masyarakat." Namun, di disi lain dosen tidak diberikan standar khusus dalam melakukan rencana kegiatannya sehingga diperlukan kesadaran diri dalam menjalankan kewajiban tridharma. Perguruan tinggi sebagai penyelenggara kegiatan sebaiknya memperhatikan kinerja dosen melalui kewajiban tridharma.

Universitas Pamulang sebagai perguruan tinggi yang menjalankan sistem pendidikan sebaiknya melakukan pengembangan organisasi untuk terutama untuk meningkatkan kinerja dosen. Pengembangan organisasi merupakan strategi organisasi yang dilakukan untuk mencapai perubahan secara organisasional. Tahap pertama dalam kegiatan ini adalah dengan melakukan diagnosis pada level individu untuk mengetahui permasalahan yang ada sehingga kemudian bisa ditentukan solusi yang sesuai untuk menyelesaikan permasalahan. Cummings (2008) dalam bukunya yang berjudul "Organizational Development and Change" menyatakan bahwa: "kinerja dipengaruhi oleh skill variety, task identity, task significance, autonomy, dan feedback about result."

Selain faktor dari pekerjaan, kinerja seseorang meningkat karena adanya faktor internal yaitu dari individu dosen berupa pengembangan karir. Rivai (2009) mengemukakan bahwa pengembangan karir adalah proses peningkatan kinerja seseorang yang dengan sadar telah direncanakan untuk dicapai demi menghasilkan karir yang diinginkan. Proses peningkatan kinerja tersebut dilakukan dengan cara melakukan perencanaan karir. Faktor lain yang dapat mempengaruhi kinerja dosen adalah kepuasan kerja dan komitmen karir. Oleh karena itu diperlukan penelitian lebih lanjut untuk mengetahui hal-hal yang berpengaruh terhadap kinerja.

\section{METODE PENELITIAN}

Instrumen penelitian yang digunakan adalah kuesioner yang diberikan secara langsung kepada responden. Sistem yang digunakan dalam kuesioner adalah dengan memberikan penilaian pada pilihan 
jawaban yang sesuai dengan kondisi yang dialami responden.

Variabel kepuasan kerja dan kinerja sebagai variabel laten endogen sebagai hasil bentukan variabel laten eksogen. Terdapat lima variabel laten eksogen yang dalam penelitian ini yaitu: 1) skill variety, 2) task identity, 3) task significance, 4) autonomy, dan 5) feedback about result, kemudian tiga variabel laten endogen yaitu komitmen, perencanaan karir, dan kinerja. Sedangkan komitmen merupakan variabel intervening yang dapat memberikan pengaruh positif maupun negatif antara perencanaan karir dengan kinerja.

Kriteria yang digunakan dalam penelitian ini adalah partial least square (PLS) dengan kriteria pada tahap evaluasi outer model sebagai berikut:

Tabel Uji validitas dan reliabilitas dalam model pengukuran PLS

\begin{tabular}{lll}
\hline $\begin{array}{c}\text { Validitas dan } \\
\text { reliabilitas }\end{array}$ & Parameter & $\begin{array}{c}\text { Rule of } \\
\text { thumb }\end{array}$ \\
\hline $\begin{array}{l}\text { Convergent } \\
\text { validity }\end{array}$ & $\begin{array}{l}\text { Faktor } \\
\text { muatan }\end{array}$ & $\geq 0.7$ \\
& $\begin{array}{l}\text { Average } \\
\text { Variance } \\
\text { Extracted } \\
\text { (AVE) }\end{array}$ & $\geq 0.7$ \\
& $\begin{array}{l}\text { Composite } \\
\text { reliability }\end{array}$ & \\
\hline
\end{tabular}

Sedangkan pada tahap inner model, digunakan evaluasi $\mathrm{R}^{2}$ pada variabel endogen untuk melihat pengaruh dari variabel eksogen.

\section{HASIL DAN PEMBAHASAN}

Analisis data menggunakan PLS menunjukkan bahwa variabel lolos uji validitas dan relabilitas kecuali career planning karena tidak memenuhi syarat AVE minimum 0,5 oleh karena itu variabel career planning didrop dari model penelitian. Pada analisis data menggunakan PLS, variabel yang dikatakan berpengaruh terhadap variabel lainnya adalah variabel yang memiliki hubungan dengan nilai tstatistik $\geq 1,96$ pada tingkat kepercayaan $95 \%$ dan path coefficient (Beta) dari tiap hubungan antar variabel yang dihipotesiskan.

Berdasarkan analisis hasil penelitian menggunakan PLS, diketahui beberapa variabel berpengaruh terhadap variabel lainnya. Hasil uji hubungan antar variabel yang digunakan untuk uji hipotesis adalah sebagai berikut.

a. Hasil pengujian hipotesis pertama menunjukkan pengaruh skill variety terhadap career satisfaction dengan nilai $\mathrm{T}$ statistik sebesar 0,858 (<1,96). Maka dapat disimpulkan bahwa: "skill variety tidak berpengaruh terhadap career satisfaction."

b. Hasil pengujian hipotesis kedua menunjukkan pengaruh task identity terhadap career satisfaction dengan nilai $\mathrm{T}$ - 
statistik sebesar 0,106 $(<1,96)$. Maka dapat disimpulkan bahwa: "task identity tidak berpengaruh terhadap career satisfaction."

c. Hasil pengujian hipotesis ketiga menunjukkan pengaruh task significance terhadap career satisfaction dengan nilai $\mathrm{T}$ statistik sebesar 0,196 (>1,96). Maka dapat disimpulkan bahwa: "task significance tidak berpengaruh terhadap career satisfaction."

d. Hasil pengujian hipotesis keempat menunjukkan autonomy berpengaruh terhadap career satisfaction karena nilai $\mathrm{T}$ statistik sebesar 3,169 (>1,96). Maka dapat disimpulkan bahwa autonomy berpengaruh positif terhadap terhadap career satisfaction dengan path coefficient sebesar 0,361 yang menjelaskan bahwa: "autonomy memberikan peran dalam meningkatkan kepuasan didalam karir dosen."

e. Hasil pengujian hipotesis kelima menunjukkan pengaruh feedback about result terhadap career satisfaction dengan nilai $\mathrm{T}$ statistik sebesar $0,719 \quad(<1,96)$ yang menjelaskan bahwa: "variabel feedback result tidak menimbulkan pengaruh pada career satisfaction."

f. Hasil pengujian hipotesis keenam, menunjukkan pengaruh Skill Variety terhadap performance dengan nilai $\mathrm{T}$ - statistik sebesar 1,298 (<1,96). Maka dapat disimpulkan bahwa: "skill variety tidak berpengaruh terhadap performance."

g. Hasil pengujian hipotesis ke tujuh, menunjukkan pengaruh task identity terhadap performance dengan nilai $\mathrm{T}$ statistik sebesar 1,627 $(<1,96)$. Maka dapat disimpulkan bahwa: "skill variety tidak berpengaruh terhadap performance."

h. Hasil pengujian hipotesis kedelapan, menunjukkan pengaruh task significance terhadap performance dengan nilai T-statistik sebesar 3,302 $(>1,96)$. Maka dapat disimpulkan bahwa task significance berpengaruh positif terhadap terhadap performance dengan path coefficient sebesar 0,283 yang menjelaskan bahwa: "task significance memberikan peran dalam meningkatkan kinerja dosen."

i. Hasil pengujian hipotesis ke sembilan menunjukkan pengaruh autonomy terhadap performance dengan nilai $\mathrm{T}$-statistik sebesar 0,351 $\quad(<1,96)$ menunjukkan bahwa: "variabel autonomy tidak menimbulkan pengaruh pada performance.

j. Hasil pengujian hipotesis ke sepuluh menunjukkan pengaruh feedback result terhadap performance dengan nilai $\mathrm{T}$ statistik sebesar 3,211 (>1,96). Maka dapat disimpulkan bahwa 
feedback result berpengaruh positif terhadap terhadap performance dengan path coefficient sebesar 0,290 yang menjelaskan bahwa: "task significance memberikan peran dalam meningkatkan kinerja dosen."

k. Hasil pengujian hipotesis kesebelas menunjukkan pengaruh career satisfaction terhadap performance dengan nilai $\mathrm{T}$ statistik sebesar 2,477 (>1,96). Maka dapat disimpulkan bahwa career satisfaction berpengaruh terhadap terhadap performance dengan path coefficient sebesar 0,184. Dikarenakan nilai koefisien berlawanan dengan hipotesis teori yang seharusnya berpengaruh positif, maka hipotesis ke-sebelas tidak diterima.

1. Nilai AVE pada variabel career planning $<0.5$ maka variabel career planning harus didrop dari model penelitian, oleh karena itu hipotesis 12 dan hipotesis 13 ditolak.

\section{KESIMPULAN}

Berdasarkan hasil analisis dan pembahasan dapat disimpulkan:

1. Autonomy berpengaruh positif terhadap career satisfaction. Hal ini menunjukkan bahwa karyawan untuk menyelesaikan pekerjaannya sendiri, sehingga kepuasan karir dapat ditingkatkan dengan menambah autonomy dalam pekerjaan dosen. Namun di sisi lain, career satisfaction diketahui berpengaruh negatif terhadap performance. Hal ini menunjukkan bahwa apabila variabel auotonomy ditingkatkan, maka akan berdampak negatif terhadap performance. Sehingga kinerja dapat ditingkatkan dengan meningkatkan faktorfaktor lain yang berpengaruh positif terhadap kinerja.

2. Task significance berpengaruh positif terhadap performance. Hal ini menunjukkan bahwa kinerja dosen dapat ditingkatkan dengan memberikan sosialisasi manfaat pekerjaan terhadap oranglain di dalam organisasi, dan di luar organisasi. Hal ini dapat digunakan oleh organisasi untuk dapat meningkatkan motivasi dosen dalam

3. Feedback about result berpengaruh positif terhadap performance. Hal ini menunjukkan bahwa kinerja dapat ditingkatkan dengan menambah informasi mengenai umpan balik kinerja dosen, umpan balik mengenai seberapa baik pekerjaan yang sudah diselesaikan, dan pemahaman mengenai baik atau buruk pekerjaan yang diselesaikan.

\section{REFERENSI}

As'ad, Moh. (2001). Psikologi Industri. Liberty. Yogyakarta.

Bernardin \& Russel, (1998). Human 
Resource Management: An Experiential Approach. New York: McGraw-Hill. Prosiding Seminar Nasional Ekonomi dan Bisnis \& Call For Paper FEB UMSIDA 2016 | 405

Blau, G. (1989). Testing Generalisability of a Career Commitment Measure and its Impact on Employee Turnover. Journal of Vocational Behaviour. 35, 88-103.

Blau, G.J., \& Boal, K. B. (1987). Conceptualizing How Job Involvement and Organizational Commitment Affect Turnover and Absenteeism. Academy of Management Review. 12, 288 300 .

Bozionelos, (2008).

Intra-organizational Network Resources: How They Relate to Career Success and Organizational Commitment. Personnel Review: Volume 37 Issue 3. pp. 249 - 263.

Davis, Keith dan Newstorm. (1996).

Perilaku dalam Organisasi Jilid 2. Jakarta. Erlangga.

Fadhillah, Muhammad. (2014).

Pengaruh Kompensasi dan

Kemampuan terhadap

Produktivitas Kerja Karyawan pada PT. Duta Palma Nusantara di Kabupaten Kuantan Singingi. JOM FEKON.

Ghozali, Imam. (2006). Structural

Equation Modeling: Metode Alternatif dengan Partial Least Square (PLS) Edisi 4. Semarang:
Badan Penerbit Universitas Diponegoro Semarang.

Greenberg, E.R., \& Baron J.A., (1993). Behavior in Organization, 4th Edition. Boston: Allyn and Bacon.

Greenhaus, J.H., Parasuraman, S.J. \& Wormley, W.M. 1990. Effects of Race on Organizational Experiences, Job Performance Evaluations, and Career Outcomes. Academy of Management Journal. 33(1): 6486.

Hariandja, Marihot T.E. (2002). Manajemen Sumber Daya Manusia. Jakarta: Grasindo.

King, A.S. (1999). Crescendo model of career motivation and commitment: Identity, insight and resilience. International Journal of Value-based Management. 12(1), 29 - 49.

Mathis Robert \& Jackson John, (2006). Manajemen Sumber Daya Manusia. Edisi 1O.Terjemahan Dian Angelica. Salemba Empat.

Maslow, A.H., Herzberg, F., dan McClelland, D. (2005). Job Satisfaction Theory.

Rivai, V. (2009). Manajemen Sumber Daya Manusia untuk Perusahaan Edisi kedua. Jakarta: PT. Raja Grafindo Persada.

Siagian Sondang, (1994), Manajemen Sumber Daya Manusia, Bumi Aksara.

Sjafri, Mangkuprawira. (2011). Manajemen Sumber Daya 
Manusia Strategik. Bogor:

Ghalia Indonesia.

Sulianti, Diana. (2009). Pengaruh

Komitmen Organisasional dan

Kepuasan Kerja Terhadap

Kinerja Karyawan PT.

Perkebunan Nusantara III di

Sumatera Utara. Jurnal

Manajemen Kewirausahaan. 